\title{
Determinants of Employee Turnover: A Case During the Covid- 19 Pandemic
}

\author{
M. M. D. R. Deegahawature ${ }^{1}$ \& H. M. I. Lakmali ${ }^{2}$ \\ ${ }^{1}$ Department of Industrial Management \\ Wayamba University of Sri Lanka \\ Kuliyapitiya \\ SRI LANKA \\ dharsana@wyb.ac.lk¹, imalkalakmali5@gmail.com²
}

\begin{abstract}
The interest of employee turnover and determinants remains because it influences the survival of firms despite wider studies. Though the Sri Lankan government promotes SMEs in economically backward provinces yet, they struggle with several human resource management issues. A sudden increase in employee turnover in a manufacturing firm located in Buttala Industrial Zone during the turbulent environment of the Covid-19 and contradictory findings about the determinants of turnover before and during the pandemic motivated the study. Therefore, this study attempts to identify the determinants of employee turnover during the Covid-19 pandemic. Crosssectional data were collected through a questionnaire that was developed using previously tested measures. Data collected from 114 respondents of the firm were analyzed by using the regression analysis. The results revealed that job satisfaction, and remuneration and benefits have a negative effect on employee turnover. Contrary to the hypotheses, the work environment characterized by organizational support and supervisor support has a positive effect. This study strengthens present literature studying human resource management practices and outcomes in a turbulent environment. Managerial implications, limitations, and future research directions are provided.
\end{abstract}

Keywords-: Employee Turnover, Covid-19 Pandemic, Determinants, Sri Lanka 


\section{INTRODUCTION}

Human capital is identified as an important and unique resource for any organization (Wang, Xu, Zhang, $\& \mathrm{Li}, 2020)$ and it becomes critical for labor-intensive industries. Therefore, retention of employees and maintaining lower employee turnover is one of the priorities in human resource departments.

Literature posits that a high turnover rate is a major problem in human resource management for a variety of reasons (Salleh, Nair, \& Harun, 2012). Employee turnover directly influences the effectiveness of an organization and is a critical strategic issue in terms of survival and sustainability (Jung, Namkung, \& Yoon, 2010). Therefore, organizations are supposed to adopt carefully developed human resource practices and strategies to mitigate employee turnover and ensure organizational sustainability.

Small and medium scale enterprises (SMEs) play a significant role in any economy irrespective of the differences among economies (Amah \& Oyetuunde, 2020). Particularly, the SMEs located in the rural areas of a country are salient since they become an important employment sector thereby, contribute to upgrade the standard of living. In the Sri Lankan context, Sri Lanka has identified the need of developing SMEs in Uva Province as it is an economically backward province (MIC, 2016). Also, the economic indicators in the province are among the lowest in the country. As an example, 52 percent of the employed population in the province engages in the agriculture sector (DCS, 2020). Out of two districts in the province, Moneragala is economically lagging behind Badulla. The number of establishments in Moneragala District is 1.8 percent out of total establishments in the country that bears 1.3 percent of employees out of total employees in the country (DCS, 2015). Thus, the support extended to develop industries in this area would help develop the province.

Though the government has identified the necessity of promoting SMEs in Uva province including Moneragala district, yet, SMEs faces several unique human resource related issues such as employee retention and higher turnover despite the fact that human resource is one of the critical resources in determining organizational success and survival (Arshad \& Puteh, 2015). The adverse effect of this issue on the firms has been intensified due to the scant of skilled employees in the Moneragala district. Also, it dilutes the strength of the skilled workforce of firms thereby, disrupts the smooth operations. Finally, organizations will not be able to achieve their goals thereby, they will not be able to contribute to the economic and social development of the area as the government expects. This study focuses on the organizations in this region with the aim of giving insight to those firms regarding employee turnover.

This study is based on a case of a limited liability company incorporated under the Companies Act in Sri Lanka. The organization is in the manufacturing industry and is 
located in Buttala Industrial Zone, Moneragala district, Uva province in Sri Lanka. This study is motivated by the fact that the focal firm has been experiencing higher employee turnover. The firm's statistics reveal that the employee turnover has increased during the Covid-19 pandemic, and it is high as 20 percent in 2020, which marks a 10 percent increase. When the employee turnover is significantly higher compared to its previous experience or similar organizations, it becomes essential to investigate the reason and take remedial actions (Armstrong, 2006). On the other hand, the studies done during the pandemic conclude contradictory findings about the determinants of employee turnover compared to the findings before the pandemic (Gunadi, Siahaan, \& Adji, 2021). Therefore, this study attempts to identify the determinants of higher employee turnover during the Covid19 pandemic.

The findings of the study help the practitioners including the firm and contribute to the literature in several ways. First, the firm will be able to identify the determinant of employee turnover during the present turbulent pandemic, and take suitable steps to mitigate the adverse effect of the issue. The present rate of turnover has drastically influenced the function and performance of the organization thus, the findings will be useful to the organization to take appropriate corrective measures to retain its competitiveness and ensure survival. Also, the retained skilled employees would help maintain higher productivity and profitability.
Second, the findings will help understand the effect of certain factors over employee turnover in distinct contexts particularly, during a turbulent time and present pandemic. It will help resolve inconsistencies in the literature. Thereby, this will contribute to strengthening the present literature. This understanding will help the organization effectively face unexpected upheavals in the future. Third, this study focuses on SMEs in an economically lagging area where the environment is distinct. The study will explore determinants of employee turnover in this unique environment. Organizations that face a similar issue in similar environments may understand and come up with appropriate solutions to cope up with the issues. The rest of the paper is organized as below. The next section is allocated to review literature related to the factors influencing employee turnover, followed by the methodology adopted in the study. The next section presents the results while the final section is devoted to discussion and conclusion.

\section{LITERATURE REVIEW}

\subsection{Employee turnover}

Employee turnover generally refers to the rate at which employees leave the firm during a given period usually, a year. CIPD (2021) defines it as "the proportion of employees who leave an organization over a set period (often on a year-on-year basis), expressed as a percentage of total workforce numbers". Armstrong (2006) defines employee turnover as the number of employees 
leaving the organization. As indicated by CIPD (2021), the employee turnover rate can be calculated as the percentage of the number of leavers in a specified period over the average number of employees during the same period. This rate indicates how effective the human resource policies, strategies, and practices of an organization are. Also, a higher rate results number of negative outcomes over the organization including decreased productivity, lower employee morale, hinder skill development, lower competitiveness, etc. (Long, Perumal, \& Ajagbe, 2012; Armstrong, 2006). Therefore, the organizations attempt to control employee turnover by bringing favorable policies, strategies, practices, etc.

This study considers the turnover intention of employees. The turnover intention does not mean that the employee departs from the organization however, it reflects the employees' mindset to leave (Abdullateef, Muktar, Yusoff, \& Ahmad, 2014). However, turnover intention is an effective indicator of employee turnover. The turnover intention may be voluntary or involuntary (Noe, Hollenbeck, Gerhart, \& Wright, 2006). Voluntary turnover refers to the departure of employees as their own decision. Accordingly, employees themselves terminate their employment based on their will. Involuntary turnover refers to the termination of employment by the employer. This study takes the definition of Mobley \& Fisk (1982) and defines the employee turnover intention as the voluntary intention of employees to quit a job or change the organization, they work for.

Retaining skilled and experienced employees by controlling employee turnover is a strategic issue that ensures sustainability (Huang, Du, \& Lin, 2021) while maintaining employee morale (Hassan \& Govindhasamy, 2020). There is a plethora of literature about employee turnover and the causes determining the same in different contexts (Ongori, 2007). Literature investigates the effect of various factors on employee turnover and these factors can be identified under diverse categories such as personal factors, organization and work factors, and social and economic factors (Zhang, 2016). Studies confirm that individual factors such as age, gender, individual skills, marital status, education, etc. influence employee turnover. Also, organization and work factors such as learning culture, job satisfaction, engagement, benefits package, involvement, relationship with superiors and peers, the scale of the firm, career growth, human resource management practices, autonomy, job stress, etc. determine the employee turnover. The literature identifies labor market characteristics, transportation system, health system, perception of the society, etc. as social and economic factors influencing the employee turnover. However, due to the unique nature of the organizations, generalizing these factors across different situations is difficult (Hassan \& Govindhasamy, 2020). Also, referring to the pandemic situation, several studies 
have investigated the effect of several factors such as job satisfaction, remuneration, benefits, work environment, perceived external employments, salary, organizational commitment, rewards, supervisor support, and poor quality of care, etc. on employee turnover (Aungsuroch, Gunawan, \& Fisher, 2022; Putri \& Arquisola, 2021; Gunadi, Siahaan, \& Adji, 2021; Lavoie- Tremblay, et al., 2021; Yorulmaz \& Sevinc, 2021).

This study focuses on the influence of four organizational factors on employee turnover. The selection of organizational factors is appropriate as this study considers the employee turnover in a selected organization. Also, the study selected the variables based on the influence of the present environment over specific variables. Accordingly, the job satisfaction, remuneration and benefits, work environment, and supervisor support were considered. The following sections present a detailed discussion on those variables and employee turnover.

\subsection{Job satisfaction}

Job satisfaction refers to how employees feel about and evaluate their job and job context, and it may be a positive or negative impression (Salleh, Nair, \& Harun, 2012). Also, it is the feeling of employees resulting after assessing various aspects of the job. In line with this definition, Locke (1976) defines job satisfaction as the pleasing or positive emotional state of employees resulting from the evaluation of their job or job environment. Spector (1997) defines it as employees' general feeling about the job or different facets of their jobs. According to Saeed, Waseem, Sikander, \& Rizwan (2014), employees get satisfied with the job when their attitudes are favorable towards this job. However, an enhanced gap between expected and available levels of different facets of the job and its context reduces job satisfaction. Employee job satisfaction affects not only employees but also employers. Job satisfaction reflects that the employees meet their expectations related to the job while it helps organizations achieve higher performance through increased employee performance (Ali \& Anwar, 2021). Considering the above facts, this study defines job satisfaction as employees' general perception about their jobs and job environment.

As mentioned earlier, job satisfaction is determined by various facets of the job. These facets include career opportunities, job influence, teamwork, and job challenge (Riyadi, 2020). Also, Spector (1997) identifies that factors such as coworkers, appreciation, challenges, job conditions, promotion, and organizational policies and procedures determine job satisfaction. According to Moorhead \& Griffin (1999) and others, facets of job satisfaction include needs and desires of employees, social relationships, management style, quality of management, job design, working conditions, long-range opportunities, opportunities outside the organization, etc. Accordingly, the literature covers a vast spectrum 
of financial and non-financial factors as determinants of job satisfaction.

Job satisfaction is identified as one of the key drives of several positive outcomes in an organization such as higher commitment, performance, engagement, productivity, responsiveness, workplace learning, and quality, etc. as well as lower absenteeism, tardiness, grievance, accidents, etc. (Ali \& Anwar, 2021; Saeed, Waseem, Sikander, \& Rizwan, 2014; Salleh, Nair, \& Harun, 2012; Armstrong, 2006; Rowden \& Conine, 2005; Spector, 1997). Also, it is recognized as an important driver of employee turnover. Investigating the association between job satisfaction and turnover intention, several authors confirm a negative association (Saeed, Waseem, Sikander, \& Rizwan, 2014). The studies conducted in western culture (Duraisingam, Pidd, \& Roche, 2009; Lee \& Rwigema, 2007) as well as in eastern culture (Alam \& Asim, 2019; Zhou, Long, \& Wang, 2009; Jiang, Baker, \& Frazier, 2009) confirms similar findings. Also, several studies conducted in the Sri Lankan context provide evidence for the negative effect of job satisfaction over employee turnover (Perera \& Madagamage, 2018; Rajapaksha \& Kappagoda, 2017; Wickramasinghe, 2010; Wickramasinghe, 2009). Research-based evidence proves that job satisfaction is low while the turnover intention is high among employees during the pandemic (Lavoie- Tremblay, et al., 2021). Analyzing the turnover intention during the Covid-19 pandemic, Gunadi, Siahaan, \& Adji (2021) conclude that job satisfaction negatively impacts it. According to these findings, employees tend to leave the organization when they are not satisfied with the job thus, the turnover intention of employees is negatively influenced by job satisfaction. Based on this ground, the following hypothesis is posited.

$\mathrm{H}_{1}$ : Job satisfaction has a negative effect on employee turnover intention.

\subsection{Remuneration and benefits}

Pay inequity is often recognized as a reason for employee turnover (Tripathi \& Srivastava, 2020; Heshizer, 1994). Not only the equity but also certain other aspects such as procedure, type, etc. influence the employee turnover (Bryant \& Allen, 2013). The procedure refers to the way organizations determine, administrate pay raises, etc. whereas the types refer to the availability of different methods of pay and benefits. Employees' satisfaction with their remuneration and benefits may positive or negative due to the outcome of the comparison between actual pay and expected pay (Locke, 1969). Two popular models, equity and discrepancy models, describe pay satisfaction as a psychological outcome of comparison of pay received against expected to receive (Wang, Chen, Hyde, \& Hsieh, 2010). Pay satisfaction is defined by Porter \& Lawler (1968) as "the feelings or affective perceptions that an individual experiences in relation to the existing pay system" (Wang, Chen, Hyde, \& Hsieh, 2010). Based on this definition, this study defines remuneration and benefits as the 
perception of employees about their experience with the present pay system in the organization.

A plethora of studies inquires about the relationship and effect of remuneration and benefits over employee turnover. These studies cover different contexts and different aspects of remuneration and benefits. Studies in developed countries confirm the existence of negative effects from pay practices on employee turnover (Pek-Greer, Wallace, \& Al-Ansaari, 2016; Guthrie, 2000). Similar results are found in the African region (Kamau \& Omondi, 2020; Lekartiwa, Rintari, $\&$ Moguche, 2020). Also, a positive effect of pay satisfaction over employee retention was found in the Asian region (A'yuninnisa \& Ridwan, 2015; Wang, Chen, Hyde, \& Hsieh, 2010). Reviewing the literature about employee retention in Pakistan, Aman-Ullah, Aziz, \& Ibrahim (2020) present a number of studies that conclude positive association and effect of remuneration and benefits over employee retention. Also, similar effects are found by several studies conducted in the manufacturing sector (Wickramasinghe \& Sajeevani, 2018; A'yuninnisa \& Ridwan, 2015). Further, several studies conducted in Sri Lanka provide evidence for the negative effect of remuneration and benefits on employee turnover. Investigating the effect of the reward system on employee turnover, Mendis (2017) finds that better financial and nonfinancial rewards strongly influence employee turnover. Importantly, compensation remuneration, and benefits are recognized as significantly and negatively influencing factors on employee turnover intention by several studies conducted in the Sri Lankan apparel sector (Fernando, 2019; Wickramasinghe \& Sajeevani, 2018; Wimalasiri \& Jayatilake, 2016; Chamini \& Randeni, 2016). Also, a significant effect of salary satisfaction over employee turnover is reported during the Covid-19 pandemic (Putri \& Arquisola, 2021). Contrary to that, Gunadi, Siahaan, \& Adji (2021) find no significant effect of remuneration on employee turnover during the pandemic. Therefore it is essential to clear this doubt. In compliance with the majority of findings, the study postulates that the perception of employees over their remuneration and benefits may negatively influence employee turnover intention. This proposition is further supported by the fact that the remuneration and benefits of employees in the focal organization consist of incentives that refer to the pay structure thus, the present pandemic may adversely affect the employee perception about present remuneration and benefits. On this ground, the following hypothesis is postulated.

$\mathrm{H}_{2}$ : Remuneration and benefits have a negative effect on employee turnover intention.

\subsection{Work environment}

The work environment is the general context where employees work. It refers to the working conditions consisting of elements that create a conducive context for the employees. Thus, it is "the perceived entirety of 
non-pecuniary elements that provide surroundings to employees' job" (Bibi, Ahmad, \& Majid, 2018). Employees will be able to work in their jobs satisfactorily, peacefully, and safely in a supportive work environment (Danish, Ramzan, \& Ahmad, 2013). Thus, it becomes an essential element for various positive employee outcomes (Verbeke, Volgering, \& Hessels, 1998). Searching for the elements of the working environment, different studies find a number of elements in different contexts (Yusof, Ibrahim, Senin, Hassan, \& Nordin, 2021; Alias, Zailan, Jahya, \& Othman, 2019; Kullab \& Kassim, 2017; Mbaruku, Larson, Kimweri, \& Kruk, 2014). As an example, the elements such as nature of work, work flexibility, challenges, dispute, working times, work schedules, etc. are identified as the elements of the work environment. The literature recognizes perceived environment (climate) as a salient dimension of the work environment. It can be defined as employees' perception of the environment, particularly about its support, organizational support, friendliness, trust, fair treatments, etc. (Yusliza, et al., 2021). On this ground, the present study defines the work environment as the perception of employees about the support received from the organizational environment.

Employees who are satisfied with their work environment are more likely to be motivated and productive. According to the literature, organizations with generous human resource policies well satisfy their employees by providing a conducive work environment, which intern increases employees' motivation to stay in the organization in long run. Thus, organizations create work environments capable of attracting, motivating, and retaining talents (Irabor \& Okolie, 2019). Contrasting to this, a difficult work environment where organization support is weaker leads to disputes thereby several negative outcomes such as job stress, burnout, absenteeism, negative attitudes, turnover, etc. (Kokt \& Ramarumo, 2015; Roelofsen, 2002). Accordingly, the existence of a supportive environment negatively impacts employee turnover (Timothy, 2009). A plethora of literature supports the argument that the work environment influences employee turnover (Bibi, Ahmad, \& Majid, 2018; Bibi, Pangil, Johari, \& Ahmad, 2017; Kundu \& Lata, 2017).

Similar results are reported by the studies conducted across the countries. Several studies conducted in Malaysia confirm that there is a negative effect of work environment on employee turnover (Yusliza, et al., 2021; Alias, Zailan, Jahya, \& Othman, 2019; Kullab \& Kassim, 2017). Studies conducted in several other countries in the same region such as Pakistan, Indonesia, India, etc. confirm the existence of a similar effect (Naz, et al., 2020; Kurniawaty, Ramly, \& Ramlaw, 2019; Umamaheswari \& Krishnan, 2016). Msengeti \& Obwogi (2015) conclude that the work environment plays a major role in determining employee turnover in the hospitality industry, Kenya. Also, the research 
provides evidence from both service (Naz, et al., 2020; Yusliza, et al., 2021; Msengeti \& Obwogi, 2015) and manufacturing industries (Kundu \& Lata, 2017; Umamaheswari \& Krishnan, 2016) for a similar effect. The limited research conducted in the Sri Lankan manufacturing sector also provides evidence for the negative effect of the work environment on employee turnover (Fernando, 2019; Chamini \& Randeni, 2016). However, the studies conducted during the Covid19 pandemic reveal that there is no significant effect of the work environment on employee turnover (Gunadi, Siahaan, \& Adji, 2021) while some studies identify workplace guidance and support as an element of employee retention (Elsafty \& Ragheb, 2020). Adapting to the majority of the findings, this study postulates that the employees' assessment and perception about the support received from the work environment may influence employee turnover. On this ground, the following hypothesis is posited.

$\mathrm{H}_{3}$ : Work environment has a negative effect on employee turnover intention.

\subsection{Supervisor support}

The literature distinguishes between organizational support and supervisor support thus, they become two distinct concepts (Kottke \& Sharafinski, 1988; Wayne, Shore, \& Liden, 1997). The organizational support is labeled here as the work environment. Some authors identify supervisor support as a dimension of perceived organizational support (Purba \& Fawzi, 2019). This study identifies it as a distinct concept that has a number of positive outcomes. As examples, organizational effectiveness (Ilyas, et al., 2020; Thomas, Bliese, \& Jex, 2005), commitment, satisfaction, productivity, and performance (Basuil, Manegold, \& Casper, 2016), etc. are among those positive outcomes. Supervisor support refers to employees' perception about the level of support and encouragement that they receive from the supervisors to carry out their jobs, and the level of concern of supervisors on employees (Burke, Borucki, \& Hurley, 1992). Accordingly, it explains the employees' assessment of the encouragement, support, and concern received from supervisors. Employees consider several factors including support for implementing achievable work practices, solving employees' issues, directing for future achievements, etc. during the assessment of supervisor support. Also, this encourages mutual support between supervisors and employees (Rafferty \& Griffin, 2006). Discussing the LMX model, Maslyn \& Uhl-Bien (2001) also insist that both supervisors and employees mutually give away trust, respect, and opinion to the other party. Thus, supervisor support is characterized by trust, respect, and opinion. Accordingly, this study defines supervisor support as the employees' perception of the support, encouragement, and care that they receive from the supervisors.

Previous studies provide evidence for the relationship and effect of supervisor support over employee 
turnover. Supervisor support is identified as a tool to reduce employee stress (Etzion, 1984) thereby, it helps reduce employee turnover through lower stress (Ilyas, et al., 2020). While several studies claim that there is no direct influence between supervisor support and turnover intention (Astuti \& Helmi, 2021), other studies conclude that there is such direct influence (Arici, 2018; Newman, Thanacoody, \& Hui, 2012). Also, literature provides evidence for the negative relationship about the focal effect across a different scale and types of organizations. As an example, Ilyas, et al. (2020) find a negative effect in SMEs while Newman, Thanacoody, \& Hui (2012) find a similar effect in multinational organizations. Several studies in the Sri Lankan context conclude that supervisor support has a negative relationship and effect on turnover intention. Also, studies find similar results in both service (Arachchi \& Dahanayake, 2020; Wijebandara, Malalage, \& Fernando, 2019; Mendis, 2017; Wickramasinghe \& Abeywardhana, 2015) and manufacturing industries (Kularathne \& Senevirathne, 2020; Tennakoon \& Herat, 2017; Dulanji \& Hettiarachchi, 2016; Chamini \& Randeni, 2016). Also, these studies cover diverse locations such as Colombo district (Wijebandara, Malalage, \& Fernando, 2019), Anuradhapura district (Dulanji \& Hettiarachchi, 2016; Arachchi \& Dahanayake, 2020), Galle district (Chamini \& Randeni, 2016), etc. On the other hand, perceived positive treatment of supervisors leads to emotional commitment within employees, in turn, it leads to motivation to stay in the organization (Purba \& Fawzi, 2019). Also, owing to its positive effect on family and career satisfaction (Karatepe \& Uludag, 2008), supervisor support may negatively affect employee turnover. Conversely, negative and abusive behavior of supervisors may increase employee turnover (Richard, Boncoeur, Chen, \& Ford, 2020). Also, the negative effect of supervisor support on employee turnover is confirmed by the studies conducted during the Covid-19 pandemic (Yorulmaz \& Sevinc, 2021). Further, employees may need special care and support from supervisors during the present pandemic since they are vulnerable to a highly turbulent environment. On this ground, the following hypothesis is postulated.

$\mathrm{H}_{4}$ : Supervisor support has a negative effect on employee turnover intention.

\section{METHODS}

Sample and data Collection: This study considers individual employee perceptions on focal variables thus, the unit of analysis was employees. As this study investigates the particular scenario in an organization located in an economically backward province outside main provinces, the employees working in a manufacturing firm located in Monaragala District in Uva Province of Sri Lanka were selected as the respondents. Data were collected during April and May 2021 when the country was at the early stage of the third wave of the Covid-19 pandemic. The data was collected through a structured questionnaire 
and the researchers directly involved in the data collection process with due permission from the firm's management as the respondents may be reluctant to provide their candid opinion for the sensitive questions regarding their present employment. Responses were anonymous and it was further ensured that none of the responses are disclosed to any external party. This procedure helps minimize the effect of social desirability bias (Podsakoff, MacKenzie, \& Podsakoff, 2012). The population was 415 employees and the study selected a sample of 150 employees by convenience sampling method, based on the requirement to perform the regression analysis (Green, 1991). Though the response rate was 100 percent, the rejection rate was 24 percent due to incomplete responses. Finally, 114 questionnaires were retained for the analysis, yielding a 76 percent net response rate. 53.39 percent of the sample were male respondents. 61.4 percent of respondents were in the age group of 30-40 years and 20.18 percent were in the age group of 41 years and above while the balance represented the age group of 29 years and below.

Measures: This study used reflective measures to operationalize constructs, and used previously validated measures. The level of agreement for each item was rated by the respondents on a 5-point Likert Scale that range from 1 (strongly disagree) to 5 (strongly agree). Cronbach's alpha statistics were above 0.60 for each construct which satisfies the minimum threshold of 0.60 (Mohamad, Sulaiman, Sern, \&
Salleh, 2015) indicating that the constructs are reliable. Also, several sociodemographic characters that may be influential on employee turnover during the Covid-19 pandemic such as gender and age were considered as control variables (Bajrami, et al., 2021; Cole, Ali, Ahmed, Hamasha, \& Jordan, 2021). The questionnaire was first developed in English and translated to the local (Sinhala) language. The translation was improved by a subject expert and a language professional. Finally, the questionnaire was given to 10 employees working in a manufacturing firm and they confirmed the clarity of the questionnaire.

Job satisfaction was measured by the 3-item scale of Michigan Organizational Assessment Questionnaire-Job Satisfaction Subscale (MOAQ-JSS) (Bowling \& Hammond, 2008). This scale has been developed by converting a 7item scale of the Michigan Organizational Assessment Questionnaire (Cammann, Fichman, Jenkins, \& Klesh, 1979) to a 3-item scale. Sample items of this scale are: "All in all I am satisfied with my job", "In general, I like working here". This scale has been widely tested and used to assess job satisfaction across a variety of contexts (Puhakka, Nokelainen, \& Pylväs, 2021; Lehtonen, Nokelainen, Rintala, \& Puhakka, 2021; Bruce, Rayton, \& Yalabik, 2014). Cronbach alpha of this scale was 0.68 .

The study employed a 6-item scale of Tessema \& Soeters (2006) to measure remuneration and benefits. 
"There is an attractive compensation system", "The salary and benefits that I received reflect the standard of living" are sample items of the scale. This scale has been widely used and tested measure of this variable (Bibi, Ahmad, \& Majid, 2018; Nawaz \& Pangil, 2016; Joarder \& Sharif, 2011; Bashir \& Khattak, 2008), and the Cronbach's alpha was 0.79 .

A 3-item scale developed by Kundu \& Lata (2017) based on the scales of Ghosh \& Sahney (2011) was employed to measure the work environment. Sample items of this scale include "Work stations in the department are comfortable", "Senior executives/managers are willing to extend cooperation in order to help employees perform their jobs to the best of their ability". A number of studies have tested this scale and used it to measure the variable in different contexts (Yusliza, et al., 2021; Yusliza, Faezah, Muhammad, \& Ramayah, 2021), and its Cronbach alpha was 0.61 .

The study employed a 4-item scale of Kottke \& Sharafinski (1988) to measure supervisor support, and sample items include, "My supervisor strongly considers my goals and values", "My supervisor really cares my well-being". This scale has been tested by a number of studies in different contexts (Yang, Huang, \& Zhou, 2021; Dhir \& Dutta, 2020; Ghazali, Nashuki, \& Othman, 2018; Rhoades, Eisenberger, \& Armeli, 2001), and reported Cronbach alpha was 0.73 .

The turnover intention was measured by a 4-item scale proposed by
(Kelloway, Gottlieb, \& Barham, 1999). Cronbach alpha was 0.61 and sample items of this scale include "I am thinking about leaving this organization" and "I am planning to look for a new job". This scale has been widely tested and used to measure turnover intention across different contexts (Lin \& Huang, 2021; Dane \& Brummel, 2013; Chen, Ployhart, Thomas, Anderson, \& Bliese, 2011).

Data analysis: The study employed regression analysis to test the hypothesis along with basic descriptive statistics and correlation. The regression analysis is appropriate as this study investigates the effect of several predictive variables on a dependent variable (Kothari, 2010).

\section{RESULTS}

Table 1 presents the results of correlation analysis along with the mean and standard deviation. Since the study used a larger sample $(n>50)$, the Kolmogorov test was used to test the normality and the test statistics $(p>0.05)$ shows that the data is normally distributed (Mishra, et al., 2019). The effect of multicollinearity was tested by the variance inflation factor (VIF). The highest VIF value was 2.03 , and it is far below the threshold value of 10 (Neter, Wasserman, \& Kutner, 1990). Thus, the results alleviate the issue of multicollinearity. DurbinWatson test statistic (1.67) is within the acceptable range of 1.5 to 2.5 (Dave \& Sohani, 2019) that confirms no-autocorrelation among variables. Assessing the overall statistical significance of the model, the 
ANOVA statistics given in the Table 2 reveal that the model is significant. Accordingly, the F-test indicates that the model is statistically reliable and can be used to explain the hypothesized effect $\quad(\mathrm{F}=13.07$, $p<0.01)$.

The results of the regression analysis are shown in Table 3. The model summary statistics shows that Rsquare is $0.33(p<.05)$. Accordingly, 35 percent of the variance in employee turnover is explained by the independent variables considered in this study. The results show that job satisfaction has a significant negative effect on the employee turnover intention $(\beta=-0.41, p<$ $.01)$, supporting the postulated effect in hypothesis 1 . Thus, hypothesis 1 is accepted. According to the results, remuneration and benefits show a significant negative effect on the employee turnover intention $(\beta=$ $0.29, p<.01)$. This supports the postulated effect in hypothesis 2 thus, hypothesis 2 is accepted. Contrary to the proposition of hypotheses 3 and 4, the results indicate a significant but, positive effect. Accordingly, work environment $(\beta=0.19, p<.10)$ and supervisor support $(\beta=0.24, p<.01)$ have positive effect over employee turnover intention. Therefore, hypotheses 3 and 4 were not accepted.

\section{DISCUSSION AND CONCLUSION}

Sri Lankan government has identified the need of developing SMEs as a strategy to develop economically lagging areas such as Moneragala District, Uva province.
However, the organizations in the area face unique human resourcesrelated issues such as high employee turnover that has intensified adverse effects on the success and sustainability of organizations. This study is motivated by the significant increase in employee turnover of the selected firm located in the Buttala Industrial Zone during the Covid-19 pandemic. Accordingly, the study attempted to identify the factors influencing employee turnover in this special context. The study investigated the effect of job satisfaction, employee remuneration, work environment, and supervisor support on employee turnover intention in this unique context.

The results of this study confirm the negative effect of job satisfaction on employee turnover during the pandemic. Present literature confirms a similar effect. As an example, in their study on large-scale technology companies, Lehtonen, Nokelainen, Rintala, \& Puhakka (2021) found a similar effect. Also, the present finding is in line with the findings of Puhakka, Nokelainen, \& Pylväs (2021) in consultancy and software developing firms. Several studies investigating this effect in the Sri Lankan context provide evidence for a negative effect (i.e. Perera \& Madagamage, 2018; Rajapaksha \& Kappagoda, 2017). The studies conducted during the pandemic confirm a similar effect (Gunadi, Siahaan, \& Adji, 2021). Thus, employees' general positive perception and emotional state about the job and job environment discourage employees' intention to depart and spur their retention. Also, this finding supports the scholars' 
claim that employees' satisfaction leads to positive outcomes.

According to the results, remuneration and benefits negatively influence employee turnover intention. Employees' positive perception about the present pay system encourages employees to retain minimizing their intention to leave. This finding does not violate the findings of the present literature. As an example, studies conducted in developed countries (Pek-Greer, Wallace, \& Al-Ansaari, 2016) and developing countries (Kamau \& Omondi, 2020) confirm a similar effect. Aungsuroch, Gunawan, and Fisher (2022) claim that rewards and benefits are essential to mitigate the turnover rate during the pandemic. Also, salary fairness is identified as a determinant of turnover intention during the Covid-19 pandemic (Putri \& Arquisola, 2021). Investigating the effect of remuneration and benefits on turnover intention in apparel manufacturing firms in Sri Lanka, (Fernando, 2019; Wickramasinghe \& Sajeevani, 2018) conclude negative effect. A similar effect is confirmed by the studies conducted during the Covid-19 pandemic (Putri \& Arquisola, 2021). While confirming the conclusions of the present literature, this study confirms the speculation that remuneration and benefits become an effective strategy across different contexts including the contexts similar to the present turbulent pandemic.

In contrast to the postulated direction of the effect, this study finds a positive effect from the work environment over the turnover intention. The work environment accessed the employees' perception about the support they receive from the organizational environment. Literature supports the fact that a difficult work environment due to less support received from the organization generates a series of negative outcomes including employee turnover (Kokt \& Ramarumo, 2015). Also, the studies in different contexts such as Malaysia (Alias, Zailan, Jahya, \& Othman, 2019), Pakistan (Naz, et al., 2020), India (Umamaheswari \& Krishnan, 2016), Sri Lanka (Fernando, 2019), service industry (Msengeti \& Obwogi, 2015), and manufacturing industry (Kundu \& Lata, 2017), etc. confirm the negative effect. Also, the effect of the work environment on employee turnover is not significant during the Covid-19 pandemic (Gunadi, Siahaan, \& Adji, 2021). However, the findings of this study are contrary to them. The context in which the present study was conducted is dissimilar to that of previous studies. The context of the present study is unique since it was conducted during a turbulent period, during the Covid19 pandemic. Hence, one possible explanation for this contrary finding may be: the turbulent environment created by the Covid-19 pandemic may moderate the relationship between work environment and employee turnover intention. This explanation is supported by the literature that confirms the existence of a moderating effect from a turbulent environment (Gyedu, Tang, Ntarmah, \& Manu, 2021; Sheng, Zhou, \& Li, 2011). Another possible reason may be: the positive 
effect may be due to the organizational support in the work environment at a level that employees do not expect. As an example, higher organizational support in the work environment may reduce employees' autonomy, flexibility, etc. that in turn, may spur the turnover intention. Thus, there may be a curvilinear relationship between these variables.

Similar to the work environment, the results indicate that the supervisor support positively influences the turnover intention, and it is inconsistent with the postulated direction. However, the literature provides evidence for the negative effect suggesting that the employees' positive perception about the support, encouragement, and care received from the supervisor leads to lower turnover intention (Burke, Borucki, \& Hurley, 1992). Several empirical studies conducted in different contexts such as SMEs (Ilyas, et al., 2020), multinational organizations

(Newman, Thanacoody, \& Hui, 2012), the service sector (Arachchi \& Dahanayake, 2020), manufacturing sector (Kularathne \& Senevirathne, 2020) confirm the negative relationship. The Sri Lankan studies also confirm the equivalent negative effect (Wijebandara, Malalage, \& Fernando, 2019; Tennakoon \& Herat, 2017). Also, a negative effect of supervisor support on employee turnover is found during the Covid19 pandemic (Yorulmaz \& Sevinc, 2021). Despite the above evidence, surprisingly, the present study finds that supervisor support positively influences turnover intention. This may be owing to the fact that the present study was conducted in a unique context, during the Covid-19 pandemic. None of the previous studies has been conducted in similar turbulent contexts. Thus, the employees may experience a distinct situation and have unique concerns due to the turbulent environment created by the Covid-19 pandemic. Therefore, one possible explanation for contradictory findings may be: the present turbulent environment may moderate the relationship between focal variables. The claim of previous studies that environment turbulent acts as a moderator (Gyedu, Tang, Ntarmah, \& Manu, 2021; Sheng, Zhou, \& Li, 2011) supports this explanation. Another possible explanation may be: this positive effect may be due to the supervisor support beyond employees' expectations that may reduce the employees' autonomy, flexibility, etc. Employees may need freedom for personal matters such as family care due to emotional commitment during a turbulent period. Also, higher supervisor support intensifies the stress thereby spurs the intention to leave. Therefore, a curvilinear relationship may exist between supervisor support and employee turnover.

In conclusion, this study concludes that certain organizational factors determine employee turnover during the present pandemic. Therefore, it is essential to concentrate and manage organizational factors during a turbulent condition such as the present pandemic. The employee turnover intention is discouraged by employee satisfaction, and 
remuneration and benefits during the pandemic. Employee positive perception about the job and jobrelated environment reduces their intention to leave. Also, employee retention is spurred by the positive perception about their experience on the pay system. However, the findings of the present study about the effect of work environment and supervisor support are contrary to the mainstream thus, the study concludes that, during the pandemic, employees' perception of both work environment and supervisor support promotes the intention to leave. Accordingly, the higher level of support, encouragement, and care received from both the organizational environment and supervisors spur employees' departure during the pandemic.

Theoretical implications: Present study makes several contributions to employee turnover literature. First, the study aims to identify the factors influencing employee turnover in a specific environment, the Covid-19 pandemic. Thus, it provides a new lens to view human resource management practices and their outcomes in a turbulent environment. Second, this study identifies that job satisfaction, and remuneration, and benefits negatively influence employee turnover. While confirming the findings of past studies, this study identifies that both become effective and valid practices across different situations and contexts. Third, this study finds that the effect of certain practices may be different in unique situations thereby stresses the importance of developing strategies, practices, etc. considering the distinct condition of the context. Because the context determines the effectiveness of certain human resource management practices. Both work environment and supervisor support have a positive influence over employee turnover.

Practical implications: This study provides several practical implications. First, job satisfaction, and remuneration and benefits are salient in determining employee turnover. The managers' attention is sought on developing and establishing long-term practices spurring job satisfaction and positive perception about remuneration and benefits. Since job satisfaction is resulted by whether employees meet their expectations related to the job and job environment, the managers should make an attempt to identify such expectations, and take steps to facilitate meeting their expectations. Also, the establishment of a fair pay system is in need to provide a positive experience to the employees. Particularly, managers can adopt these two practices in different situations disregarding the differences across situations. Second, both the work environment that measures organizational support and supervisor support should be handled carefully. Positive effects found in this study demand the managers' attention on the optimal level of both work environment and supervisor support in developing and implementing practices to mitigate employee turnover. Also, the cross effect of such practices over other outcomes such as tardiness, absenteeism, productivity, etc. 
should be assessed. Particularly, the effect of human resource management practices in dissimilar contexts should be given attention. Third, the human resource managers in the geographical area covered by the present study may get an insight into developing their human resource practices.

Limitations and future research directions: This study has some limitations and those limitations open new research opportunities. Though the study delivered useful insight into employee turnover during the pandemic, it was limited to one manufacturing firm located in Moneragala district, Uva province in Sri Lanka limiting the generalizability of findings. Thus, new research may be conducted in the other organizations located within and outside the focal geographical area during the pandemic. Second, though the testing of well-established relationships in a distinct context such as the present pandemic is salient (Eden, 2002), the findings related to the work environment and supervisor support are contrary to the mainstream. The turbulent environment created by the Covid-19 pandemic may influence these conflicting findings. However, this study did not consider any moderating effects. Therefore, future studies may inquire about the moderating effect of certain contextual variables such as the turbulent environment. On the other hand, these contradictory findings may be due to the existence of a curvilinear relationship between focal variables. Thus, future studies may investigate the possibility of having a threshold or optimal level of work environment covering organizational support, and supervisor support. Third, this study was based on cross-sectional data that may lead to biased responses since the responses are based on respondents' distinct experiences at the point of data collection. Since both variables that are found contrary to the literature are related to the employees' perception about the support received from the organization and supervisors, crosssectional data may depend on the unique experience of respondents at the point of data collection. This situation may influence the variables. The possibility of biased responses may be higher since respondents are vulnerable to an unanticipated environment due to the Covid-19 pandemic. Also, the suggestion for the longitudinal approach is supported by the fact that the responses for focal variables should be based on the long-term experience of the respondents. Also, it may allow for the comparison of the situation during and after the Covid19 pandemic, and help better understand the effect. Thus, future studies may adopt the longitudinal approach. 


\section{APPENDIX}

Table 1: Basic descriptive statistics and correlations

\begin{tabular}{|l|c|c|c|c|c|c|}
\hline & Mean & SD & $\mathbf{1}$ & $\mathbf{2}$ & $\mathbf{3}$ & $\mathbf{4}$ \\
\hline 1. Emp. turnov. & 3.34 & .35 & 1 & - & - & - \\
\hline 2. Job satisfact. & 3.48 & .25 & -.05 & 1 & - & - \\
\hline 3. Remu. \& ben. & 3.20 & .46 & $-.42 * *$ & -0.06 & 1 & - \\
\hline 4. Work enviro. & 3.47 & .39 & $.33 * *$ & $.53 * *$ & $-.32 * *$ & 1 \\
\hline 5. Supe. support & 3.31 & .43 & $.28 * *$ & $.40 * *$ & .03 & $.54 * *$ \\
\hline
\end{tabular}

$* * p<.01, * p<.05$

Source: Results of the analysis

Table 2: ANOVA table

\begin{tabular}{|l|c|c|c|c|c|}
\hline & $\begin{array}{c}\text { Sum of } \\
\text { Squares }\end{array}$ & df & $\begin{array}{c}\text { Mean } \\
\text { Square }\end{array}$ & F & Sig. \\
\hline Regression & 4.44 & 4 & 1.109 & 13.07 & $.000^{\mathrm{b}}$ \\
\hline Residual & 9.25 & 109 & .085 & & \\
\hline & 13.69 & & & & \\
\hline
\end{tabular}

Predictors: (Constant), Job satisfaction, Remu. \& benefits, Work envt., Supervisor support

Source: Results of the analysis

Table 3: Regression analysis

\begin{tabular}{|l|c|c|c|c|}
\hline \multirow{2}{*}{ Variable } & \multicolumn{2}{|c|}{$\begin{array}{c}\text { Unstandardized } \\
\text { Coefficient }\end{array}$} & $\begin{array}{c}\text { Standardized } \\
\text { Coefficient } \\
\text { Beta }\end{array}$ & $p$ \\
\cline { 2 - 3 } & $\mathrm{B}$ & $\mathrm{SE}$ & & .000 \\
\hline Constant & $4.258^{*}$ & .458 & & .002 \\
\hline Job satisfaction & $-.411^{*}$ & .131 & -.296 & .000 \\
\hline Remu. \& benef. & $-.290^{*}$ & .066 & -.380 & .068 \\
\hline Work environm. & $.187^{*} *$ & .102 & .207 & .003 \\
\hline Supervi. support & $.239^{*}$ & .079 & .297 & .37 \\
\hline $\mathrm{R}$ & & & .30 \\
\hline $\mathrm{R}^{2}$ & & & \\
\hline Adjusted $\mathrm{R}^{2}$ & & & \\
\hline
\end{tabular}

$\mathrm{N}=114 ; * * p<.05, * p<.10$

Source: Results of the analysis 


\section{REFERENCES}

A'yuninnisa, R. N., \& Ridwan, S. (2015). The effects of pay satisfaction and affective commitment on turnover intention. International Journal of Research Studies in Psychology, 4 (2), 57-70. https://doi.org/10.5861/ijrsp.20 15.1055 .

Abdullateef, A. O., Muktar, S. S., Yusoff, R. Z., \& Ahmad, I. S. (2014). Effects of customer relationship management strategy on call centre's employee intention to quit: Evidence from Malaysia Call Centers. Procedia - Social and Behavioral Sciences, 130 (2), 305-315. https://doi.org/10. 1016/j.sbspro.2014.04.036.

Alam, A., \& Asim, M. (2019). Relationship between job satisfaction and turnover intention. International Journal of Human Resource Studies, 9 (2), 196-194. https://doi.org/10. 5296/ijhrs.v9i2.14618.

Ali, B. J., \& Anwar, G. (2021). An empirical study of employees' motivation and its influence job satisfaction. International Journal of Engineering, Business and Management, 5 (2), 21-30. https://doi.org/10. 22161/ijebm.5.2.3.

Alias, N. E., Zailan, N. A., Jahya, A., \& Othman, R. (2019). The effect of supportive work environment on employee retention at malaysia information, communication, and technology (ICT) industry. International Journal of Academic Research in Business and Social Sciences, 9 (8), 6167. http://dx.doi.org/10.6007/ IJARBSS/v9-i8/6210 .

Amah, O. E., \& Oyetuunde, K. (2020). The effect of servant leadership on employee turnover in SMEs in Nigeria: The role of career growth potential and employee voice. Journal of Small Business and Enterprise Development, 27(6), 1462-6004. https://doi.org/10.1108/JSBED -01-2019-0009.

Aman-Ullah, A., Aziz, A., \& Ibrahim, H. (2020). A systematic review of employee retention: What's next in Pakistan? Journal of Contemporary Issues and Thought, 10 (2), 36-45. https://doi.org/10.37134/jcit.vo 110.sp.4.2020.

Arachchi, W. K., \& Dahanayake, S. N. (2020). Impact of human resource management practices on turnover intention of housekeeping employees in hotels in Anuradhapura. 3rd National Research Symposium on Management. Anuradhapura: Faculty of 
Management Studies, Rajarata University of Sri Lanka.

Arici, H. E. (2018). Perceived supervisor support and turnover intention: Moderating effect of authentic leadership. Leadership \& Organization Development Journal, 39 (7), 899-913. https://doi.org/10. 1108/LODJ-07-2018-0248.

Armstrong, M. (2006). A handbook of human resource management practice 10ed. London: Kogan Page.

Arshad, H., \& Puteh, F. (2015). Determinants of turnover intention among employees. Journal of Administrative Science, 12 (2), 1-15. https://ir.uitm.edu.my/id/eprint/ 44739.

Astuti, T., \& Helmi, A. F. (2021). Perceived supervisor support and turnover intention: A metaanalysis study. Buletin Psikologi, 29 (1), 1-13. https://doi.org/10.22146/buleti npsikologi.54366.

Aungsuroch, Y., Gunawan, J., \& Fisher, M. L. (2022). Redesigning the nursing and human resource partnership. In Rewards and benefits (pp. 6168). Singapore. https://doi.org/ 10.1007/978-981-16-5990-4_5: Palgrave Macmillan.
Bajrami, D. D., Terzić, a., Petrović, M. D., Radovanović, M., Tretiakova, T. N., \& Hadoud, A. (2021). Will we have the same employees in hospitality after all? The impact of COVID-19 on employees' work attitudes and turnover intentions. International Journal of Hospitality Management, $\quad 94$ (April), 102754. https://doi.org/10.1016 /j.ijhm.2020.102754.

Bashir, S., \& Khattak, H. R. (2008). Impact of selected HR practices on perceived employee performance, a study of public sector employees in Pakistan. European Journal of Social Sciences, 5 (4), 243-252.

Basuil, D. A., Manegold, J. G., \& Casper, W. J. (2016). Subordinate perceptions of family- supportive supervision: the role of similar family- related demographics and its effect on affective commitment. Human Resource Management Journal, 26 (4), 523-540.

https://doi.org/10.1111/17488583.12120 .

Bibi, P., Ahmad, A., \& Majid, A. H. (2018). HRM practices and employee retention: The moderating effect of work environment. In F. Ali, S. M. Rasoolimanesh, \& C. Cobanoglu, Applying partial least squares in tourism and hospitality research (pp. 129- 
152). Bingley: Emerald Publishing Limited. https://doi.org/10.1108/978-178756-699-620181007.

Bibi, P., Pangil, F., Johari, J., \& Ahmad, A. (2017). The impact of compensation and promotional opportunities on employee retention in academic institutions: The moderating role of work environment. International Journal of Economic Perspectives, 11 (1), 378-391. http://repo.uum.edu. my/id/eprint/26102.

Bowling, N. A., \& Hammond, G. D. (2008). A meta-analytic examination of the construct validity of the Michigan Organizational Assessment Questionnaire Job Satisfaction Subscale. Journal of Vocational Behavior, 73 (1), 63-77. https://doi.org/10.1016/j.jvb.20 08.01.004.

Bruce, A., Rayton, B. A., \& Yalabik, Z. Y. (2014). Work engagement, psychological contract breach and job satisfaction. The International Journal of Human Resource Management, 25 (17), 23822400. https://doi.org/10.1080/ 09585192.2013.876440.

Bryant, P. C., \& Allen, D. G. (2013). Compensation, benefits and employee turnover: HR strategies for retaining top talent. Compensation \& Benefits Review, 45 (3), 171-
175. https://doi.org/10.1177/08 86368713494342.

Burke, M. J., Borucki, C. C., \& Hurley, A. E. (1992). Reconceptualizing psychological climate in a retail service environment: A multiplestakeholder perspective. Journal of Applied Psychology, 77 (5), 717-729. https://doi.org/ 10.1037/0021-9010.77.5.717.

Cammann, C., Fichman, M., Jenkins, D., \& Klesh, J. (1979). The Michigan Organizational Assessment Questionnaire. Michigan: University of Michigan.

Chamini, H. G., \& Randeni, R. K. (2016). Examine the relationship between organizational factors and employee turnover in apparel industry in Sri Lanka. Journal of Business Studies, 3 (1), 1428. http://doi.org/10.4038/jbs. v3i1.28.

Chen, G., Ployhart, R. E., Thomas, H. C., Anderson, N., \& Bliese, P. D. (2011). The power of momentum: A new model of dynamic relationships between job satisfaction change and turnover intentions. Academy of Management Journal, 54 (1), 159-181. https://doi.org/10. 5465/amj.2011.59215089.

CIPD. (2021, 06 25). Employee turnover and retention. Retrieved from Chartered Institute of Personnel and 
Development: https://www. cipd.co.uk/knowledge/strategy/ resourcing/turnover-retentionfactsheet

Cole, A., Ali, H., Ahmed, A., Hamasha, M., \& Jordan, S. (2021). Identifying patterns of turnover intention among alabama frontline nurses in hospital settings during the COVID-19 pandemic. Journal of Multidisciplinary Healthcare, 14(Jul.), 17831794. https://doi.org/10.2147/ JMDH.S308397.

Dane, E., \& Brummel, B. J. (2013). Examining workplace mindfulness and its relations to job performance and turnover intention. Human Relations, 67 (1), 105-128. https://doi.org/10. $1177 / 0018726713487753$.

Danish, R. Q., Ramzan, S., \& Ahmad, F. (2013). Effect of perceived organizational support and work environment on organizational commitment: mediating role of self monitoring. Advances in Economics and Business, 1 (4), 312-317. https://doi.org/10.131 89/aeb.2013.010402.

Dave, Y., \& Sohani, N. (2019). Improving productivity through Lean practices in central Indiabased manufacturing industries. International Journal of Lean Six Sigma, 10 (2), 601-621. https://doi.org/10.1108/IJLSS10-2017-0115.
DCS. (2015). Non-agricultural economic activities in Sri Lanka - Economic census 2013/2014. Colombo: Department of Census and Statics .

DCS. (2020). Economic Statistics of Sri Lanka 2020. Colombo: Department of Sensus and Statistics.

Dhir, S., \& Dutta, T. (2020). Linking supervisor-support, person-job fit and personorganization fit to company value. Journal of Indian Business Research, 12 (4), 1755-4195. https://doi.org/10. 1108/JIBR-04-2019-0124.

Dulanji, S. D., \& Hettiarachchi, H. A. (2016). An Assessment of Factors Affecting voluntary labor turnover intention in apparel industry (with special reference to MAS Holdings (Pvt) Ltd; Mihintale). 5th International Conference of Sri Lanka Forum of University Economists (pp. 138-141). Kelaniya: SLFUE, University of Kelaniya.

Duraisingam, V., Pidd, K., \& Roche, A. M. (2009). The impact of work stress and job satisfaction on turnover intentions: a study of Australian specialist alcohol and other drug workers. Drugs: Education, Prevention and Policy, 16 (3), 217-231. https://doi.org/10.1080/096876 30902876171. 
Eden, D. (2002). From the editors: replication, meta-analysis, scientific progress, and AMJ's publication policy. Academy of Management Journal, 45 (5), 841-846. https://www.jstor.org/ stable/3069317.

Elsafty, A. S., \& Ragheb, M. (2020). The role of human resource management towards employees retention during Covid-19 pandemic in medical supplies sector-Egypt. Business and Management Studies, 6(2), 5059-5059. https://doi.org/10. 11114/bms.v6i2.4899.

Etzion, D. (1984). Moderating effect of social support on the stress-burnout relationship. Journal of applied psychology, 69 (4), 615-622. https://doi.org /10.1037/0021-9010.69.4.615.

Fernando, A. G. (2019). Factors Impact on Employee Turnover with Special Reference to the Apparel Industry in Sri Lanka. International Journal of Research and Innovation in Social Science, 9 (3), 184-187.

Ghazali, H., Nashuki, N. M., \& Othman, M. (2018). The influence of perceived organizational support (pos), perceived supervisory support (pss) and organizational commitment (oc) towards intention to leave or intention to stay: A case of casual dining restaurants in Klang Valley,
Malaysia. International Journal of Academic Research in Business and Social Sciences, 8 (9), 1884-1902. http://dx.doi. org/10.6007/IJARBSS/v8i9/4869.

Ghosh, K., \& Sahney, S. (2011). Impact of organizational sociotechnical system on managerial retention: A general linear modeling approach. Journal of Modelling in Management, 6 (1), 33-59. https://doi.org/10.1108/174656 61111112494.

Green, S. B. (1991). How many subjects does it take to do a regression analysis. Multivariate Behavioral Research, 26 (3), 499-510. https://doi.org/10.1207/s15327 906mbr2603_7.

Gunadi, L., Siahaan, A., \& Adji, A. (2021). Turnover intention analysis in digitalization era within Covid-19 pandemic situation. Emerging Markets: Business and Management Studies Journal, 9(1), 19-33.

Guthrie, J. P. (2000). Alternative pay practices and employee turnover: An organization economics perspective. Group \& Organization Management, 25 (4), 419-439. https://doi.org/ $10.1177 / 1059601100254006$.

Gyedu, S., Tang, H., Ntarmah, A. H., \& Manu, E. K. (2021). The moderating effect of 
environmental turbulence on the relationship between innovation capability and business performance.

International Journal of Innovation Science, In press, In press. https://doi.org/10.1108/ IJIS-10-2020-0189.

Hassan, Z., \& Govindhasamy, C. (2020). An investigation on extrinsic and intrinsic rewards on employee retention among Gen Y: A study in Malaysian manufacturing companies. Journal of Business and Economic Analysis, 3 (1), 5569. https://doi.org/10.36924/ sbe.2020.3104.

Heshizer, B. (1994). The impact of flexible benefits plans on job satisfaction, organizational commitment, and turnover intentions. Benefits Quarterly, 10, 84-90.

Huang, I., Du, P., \& Lin, C. S. (2021). Leader-member exchange, employee turnover intention and presenteeism: the mediating role of perceived organizational support. Leadership \& Organization Development Journal 42(2), 249-264. https://doi.org/10. 1108/LODJ-03-2020-0094.

Ilyas, A., Khan, A. H., Zaid, F., Ali, M., Razzaq, A., \& Khan, W. (2020). Turnover intention of employees, supervisor support, and open innovation: The role of illegitimate tasks. Journal of
Open Innovation: Technology, Market \& Complexity, 6 (4), 128-139. https://doi.org/10. 3390/joitmc6040128.

Irabor, I. E., \& Okolie, U. C. (2019). A review of employees' job satisfaction and its affect on their retention. Annals of Spiru Haret University. Economic Series, 19 (2), 93-114. https://doi.org/10.26458/1924.

Jiang, B., Baker, R. C., \& Frazier, G. V. (2009). An analysis of job dissatisfaction and turnover to reduce global supply chain risk: Evidence from China. Journal of Operations Management, 27 (2), 169-184. https://doi.org/10. 1016/j.jom.2007.09.002.

Joarder, M. H., \& Sharif, M. Y. (2011). The role of HRM practices in predicting faculty turnover intention: empirical evidence from private universities in Bangladesh. The South East Asian Journal of Management, 5 (2), 159-178. https://doi/org/10.21002/seam. v5i2.979.

Jung, H. S., Namkung, Y., \& Yoon, H. H. (2010). The effects of employees' business ethical value on person-organization fit and turnover intent in the foodservice industry. International Journal of Hospitality Management, 29 (3), 538-546. https://doi.org/10. 1016/j.ijhm.2009.08.005. 
Kamau, J., \& Omondi, M. (2020). Influence of remuneration on employee retention in commercial banks in Kenya. International Research Journal of Business and Strategic Management, 1 (1), 104-114.

Karatepe, O. M., \& Uludag, O. (2008). Supervisor support, work-family conflict, and satisfaction outcomes: An empirical study in the hotel industry. Journal of Human Resources in Hospitality \& Tourism, 7 (2), 115-134. https://doi.org/10.1080/153328 40802156824.

Kelloway, E. K., Gottlieb, B. H., \& Barham, L. (1999). The source, nature, and direction of work and family conflict: a longitudinal investigation. Journal of Occupational Health Psychology, 4 (4), 337-346. https://doi.org/10.1037/10768998.4.4.337.

Kokt, D., \& Ramarumo, R. (2015). Impact of organisational culture on job stress and burnout in graded accommodation establishments in the Free State province, South Africa. International Journal of Contemporary Hospitality Management, 27 (6), 11981213. https://doi.org/10.1108/ IJCHM-03-2014-0100.

Kothari, C. R. (2010). Quantative techniques, 3ed. New Delhi: Vikas Publishing House.
Kottke, J. L., \& Sharafinski, C. E. (1988). Measuring perceived supervisory and organizational support. Educational and psychological Measurement, 48 (4), 1075-1079. https://doi.org/ 10.1177/0013164488484024.

Kularathne, H. M., \& Senevirathne, Y. Y. (2020). The relationship between co-worker support, supervisor support, organizational support and employee turnover intention of operational level employees in apparel sector, Central Province, Sri Lanka. International Journal of Creative and Innovative Research, 2 (8), 7-17.

Kullab, M. A., \& Kassim, R. N. (2017). Determinants of working environment, employee loyalty and employee turnover of ICT-SME industry. World Journal of Research and Review, 5(5), 6-8.

Kundu, S. C., \& Lata, K. (2017). Effects of supportive work environment on employee retention: Mediating role of organizational engagement. International Journal of Organizational Analysis, 25(4), 703-722. https://doi.org/10. 1108/IJOA-12-2016-1100.

Kurniawaty, K., Ramly, M., \& Ramlaw, R. (2019). The effect of work environment, stress, and job satisfaction on employee turnover intention. 
Management Science Letters, 9 (6), 877-886.

Lavoie- Tremblay, M., Gélinas, C., Aube, T., Tchouaket, E., Tremblay, D., Gagnon, M. P., \& Côté, J. (2021). Influence of caring for COVID- 19 patients on nurse's turnover, work satisfaction and quality of care. Journal of Nursing Management., 1-11.

Lee, G. J., \& Rwigema, h. (2007). Mobley revisited: Dynamism in the process of employee turnover. International Journal of Human Resource management, 16 (9), 16711690. https://doi.org/10.1080/ 09585190500239333.

Lee, J., Back, K., \& Chan, E. S. (2015). Quality of work life and job satisfaction among frontline hotel employees: A selfdetermination and need satisfaction theory approach. International Journal of Contemporary Hospitality Management, 27 (5), 768-789. https://doi.org/10.1108/IJCHM -11-2013-0530.

Lehtonen, E. E., Nokelainen, P., Rintala, H., \& Puhakka, I. (2021). Thriving or surviving at work: How workplace learning opportunities and subjective career success are connected with job satisfaction and turnover intention? Journal of Workplace Learning, (In press).
https://doi.org/10.1108/JWL12-2020-0184.

Lekartiwa, H., Rintari, N., \& Moguche, A. (2020). Effects of remuneration on employee turnover in private hospitals Samburu County. Human Resource and Leadership Journal, 5 (1), 15-28. https://doi.org/10.47941/hrlj.42 3.

Lin, C. Y., \& Huang, C. K. (2021). Employee turnover intentions and job performance from a planned change: The effects of an organizational learning culture and job satisfaction. International Journal of Manpower, 42 (3), 409-423. https://doi.org/10.1108/IJM08-2018-0281.

Locke, E. A. (1969). What is job satisfaction? Organizational Behavior and Human Performance, 4 (4), 309-336. https://doi.org/10.1016/00305073(69)90013-0.

Locke, E. A. (1976). The nature and causes of job satisfaction. In M. D. Dunnette, Handbook of industrial and organizational psychology,1297-1347.

Chicago: Rand McNally.

Long, C., Perumal, P., \& Ajagbe, A. (2012). The impact of human hesource management practices on employees' turnover intention: A conceptual model. 
Interdisciplinary Journal of Contemporary Research in Business, 4(2), 629-641.

Maslyn, J. M., \& Uhl-Bien, M. (2001). Leader-member exchange and its dimensions: Effects of self-effort and other's effort on relationship quality. Journal of Applied Psychology, 86 (4), 697-708. https://doi.org/ 10.1037/0021-9010.86.4.697.

Mbaruku, G. M., Larson, E., Kimweri, A., \& Kruk, M. E. (2014). What elements of the work environment are most responsible for health worker dissatisfaction in rural primary care clinics in Tanzania? Human Resources for Health, 12, 1-9. http://www.humanresources-health.com/content/ 12/1/38.

Mendis, M. V. (2017). The impact of reward system on employee turnover intention: A study on logistics industry of Sri Lanka. International Journal of Scientific \& Technology Research, 6 (9), 67-72.

MIC. (2016). National policy framework for small and medium enterprises (SMEs) development - Action plan. Colombo: Ministry of Industry and Commerce.

Mishra, P., Pandey, C. M., Singh, U., Gupta, A., Sahu, C., \& Keshri, A. (2019). Descriptive statistics and normality tests for statistical data. Annals of Cardiac Anaesthesia, 22 (1), 67-72. https://doi.org/10.4103/ aca.ACA_157_18.

Mobley, W., \& Fisk, M. (1982). Employee turnover: Causes, consequences, and control. Boston: Addison-Wesley.

Mohamad, M. M., Sulaiman, N. L., Sern, L. C., \& Salleh, K. M. (2015). Measuring the validity and reliability of research instruments. Procedia-Social and Behavioral Sciences, 204, 164-171. https://doi.org/10. 1016/j.sbspro.2015.08.129.

Moorhead, G., \& Griffin, R. W. (1999). Organizational behavior - Managing people and organizations. Delhi: AITBS Publishers.

Msengeti, D. M., \& Obwogi, J. (2015). Effects of pay and work environment on employee retention: A study of hotel industry in Mombasa county. International Journal of Scientific and Research Publications, 5 (4), 1-10. http://hdl.handle.net/12345678 9/5132.

Nawaz, M., \& Pangil, F. (2016). The relationship between human resource development factors, career growth and turnover intention: The mediating role of organizational commitment. Management Science Letters, 6 (2), 157-176. 
http://dx.doi.org/10.6007/IJAR BSS/v5-i12/1959.

Naz, S., Li, C., Nisar, Q. A., Khan, M. A., Ahmad, N., \& Anwar, F. (2020). A study in the relationship between supportive work environment and employee retention: role of organizational commitment and person-organization fit as mediator. SAGE Open, 10 (2), 1-20. https://doi.org/10.1177/ 2158244020924694.

Neter, J., Wasserman, W., \& Kutner, M. H. (1990). Applied linear statistical models. Homewood, IL: Irwin.

Newman, A., Thanacoody, R., \& Hui, W. (2012). The effects of perceived organizational support, perceived supervisor support and intraorganizational network resources on turnover intentions: A study of Chinese employees in multinational enterprises. Personnel Review, 41 (1), 56-72. https://doi.org/ $10.1108 / 00483481211189947$.

Noe, R. A., Hollenbeck, J. R., Gerhart, B., \& Wright, P. M. (2006). Human resources management gaining a competitive advantage. 4ed. New York: McGraw Hill.

Ongori, H. (2007). A review of the literature on employee turnover. African Journal of
Business Management, 6, 4954. http://hdl.handle.net/10311 /1154.

Pek-Greer, P., Wallace, M., \& AlAnsaari, Y. (2016). Do human resource practices, employee remuneration and employee benefits have significant influence on the retention of childcare teachers in the childcare service industry? Asian Academy of Management Journal 21 (1), 1-26.

Perera, G. D., \& Madagamage, G. T. (2018). The impact of job satisfaction and organizational commitment on intention to turnover in the Sri Lankan hospitality industry: Perceptions from the generation Y view point. Sri Lankan Journal of Human Resource Management, 8 (1), 23-35.

Podsakoff, P. M., MacKenzie, S. B., \& Podsakoff, N. (2012). Sources of method bias in social science research and recommendations on how to control it. Annual review of psychology, 63, 539-569. https://doi.org/10.1146/annurev -psych-120710-100452.

Porter, L. W., \& Lawler, E. E. (1968). Managerial attitudes and performance. Homewood, IL: R. D. Irwin Inc.

Puhakka, I. J., Nokelainen, P., \& Pylväs, L. (2021). Learning or 
leaving? Individual and environmental factors related to job satisfaction and turnover intention. Vocations and Learning (In press), 1-30. https://doi.org/10.1007/s12186021-09275-3.

Purba, D. E., \& Fawzi, A. R. (2019). The effects of perceived supervisor support and servant leadership on voluntary turnover. Humaniora, 10 (3), 211-217. https://doi.org/10. 21512/humaniora.v10i3.5818.

Putri, K., \& Arquisola, M. J. (2021). Influence of salary satisfaction and organizational commitment towards turnover intentions during Covid-19 pandemic situations. Proceedings of International Conference Universitas Pekalongan 2021 (pp. 91-98). Jawa Tengah: Universitas Pekalongan.

Rafferty, A. E., \& Griffin, M. A. (2006). Perceptions of organizational change: A stress and coping perspective. Journal of Applied Psychology, 91 (5), 1154-1162. https://doi.org/10. 1037/0021-9010.91.5.1154.

Rajapaksha, U. R., \& Kappagoda, U. W. (2017). Factors affecting to turnover intention of nonmanagerial employees in apparel industry: A Sri Lankan experience. International Journal of Managerial Studies and Research, 5 (11), 76-82. https://ssrn.com/abstract=3076 783.

Rhoades, L., Eisenberger, R., \& Armeli, S. (2001). Affective commitment to the organization: The contribution of perceived organizational support. Journal of applied psychology, 86 (5), 825-836. https://doi.org/10.1037/00219010.86.5.825.

Richard, O. C., Boncoeur, O. D., Chen, H., \& Ford, D. L. (2020). Supervisor abuse effects on subordinate turnover intentions and subsequent interpersonal aggression: The role of powerdistance orientation and perceived human resource support climate. Journal of Business Ethics, 164, 549-563. https://doi.org/10.1007/s10551018-4019-7.

Riyadi, S. (2020). The influence of leadership style, individual characteristics and organisational climate on work motivation, job satisfaction and performance. International Journal of Innovation, Creativity and Change, 13(7), 662-677.

Roelofsen, P. (2002). The impact of office environments on employee performance: The design of the workplace as a strategy for productivity enhancement. Journal of Facilities Management, 1 (3), 
247-264. https://doi.org/10. 1108/14725960310807944.

Rowden, R. W., \& Conine, C. T. (2005). The impact of workplace learning on job satisfaction in small US commercial banks. Journal of Workplace Learning, 17(4), 215-230. https://doi.org/10. 1108/13665620510597176.

Saeed, I., Waseem, M., Sikander, S., \& Rizwan, M. (2014). The relationship of turnover intention with job satisfaction, job performance, leader member exchange, emotional intelligence and organizational commitment. International Journal of Learning and Development, 4(2), 242-256. http://dx.doi.org/10.5296/ ijld.v4i2.6100.

Salleh, R., Nair, M. S., \& Harun, H. (2012). Job satisfaction, organizational commitment, and turnover intention: A case study on employees of a retail company in Malaysia. World Academy of Science, Engineering and Technology, International Journal, 6 (12), 3429-3436. https://doi.org/10. 5281/zenodo.1070727.

Sheng, S., Zhou, K. Z., \& Li, J. J. (2011). The Effects of business and political ties on firm performance: Evidence from China. Journal of Marketing,
75 (1), 1-15. https://doi.org/10. 1509/jm.75.1.1.

Spector, P. E. (1997). Job satisfaction: Application, assessment, cause and consequences. Thousand Oaks: Sage.

Tennakoon, W. D., \& Herat, U. L. (2017). Perceived supervisor support and employee turnover intention: The moderating effect of employment tenure. Wayamba Journal of Management, 8 (1), 14-26. http://doi.org/10.4038/wjm.v8i 1.7505 .

Tessema, M. T., \& Soeters, J. L. (2006). Challenges and prospects of HRM in developing countries: testing the HRM-performance link in the Eritrean civil service. The international journal of human resource management, 17 (1), 86-105. https://doi.org/10. 1080/09585190500366532.

Thomas, J. L., Bliese, P. D., \& Jex, S. M. (2005). Interpersonal conflict and organizational commitment: Examining two levels of supervisory support as multilevel moderators. Journal of Applied Social Psychology, 35 (11), 2375-2398. https://doi.org/10.1111/j.15591816.2005.tb02107.x.

Tripathi, A., \& Srivastava, R. (2020). A literature review on turnover and retention of IT 
employees. International Journal of Advanced Science and Technology, 29 (3), 675683. http://sersc.org/journals/ index.php/IJAST/article/view/3 0391.

Umamaheswari, S., \& Krishnan, J. (2016). Workforce retention: Role of work environment, organization commitment, supervisor support and training \& development in ceramic sanitary ware industries in India. Journal of Industrial Engineering and Management, 9 (3), 612-633. http:// dx.doi.org/10.3926/jiem.1885.

Verbeke, W., Volgering, M., \& Hessels, M. (1998). Exploring the conceptual expansion within the field of organizational behaviour: Organizational climate and organizational culture. Journal of Management Studies, 35 (3), 303-329. https://doi.org/10. 1111/1467-6486.00095.

Wang, C. Y., Chen, M. H., Hyde, B., \& Hsieh, L. (2010). Chinese employees' work values and turnover intentions in multinational companies: The mediating effect of pay satisfaction. Social Behavior and Personality: An International Journal, 38 (7), 871-878. https://doi.org/10. 2224/sbp.2010.38.7.871.

Wang, C., Xu, J., Zhang, T. C., \& Li, Q. M. (2020). Effects of professional identity on turnover intention in China's hotel employees: The mediating role of employee engagement and job satisfaction. Journal of Hospitality and Tourism Management, 45, 10-22. https://doi.org/10.1016/j.jhtm.2 020.07.002.

Wayne, S. J., Shore, L. M., \& Liden, R. C. (1997). Perceived organizational support and leader-member exchange: A social exchange perspective. Academy of Management Journal, 40 (1), 82-111. https: //doi.org/10.5465/257021.

Wickramasinghe, A. I., \& Abeywardhana, D. K. (2015). Factors effect on employee turnover intention: Evidence from leasing industry in Sri Lanka. International Postgraduate Research Conference (p. 26). Kelaniya: University of Kelaniya.

Wickramasinghe, M. D., \& Sajeevani, T. L. (2018). The impact of rewards on retention of operational level employees in three apparel sector companies in export processing zone in Biyagama. Human Resource Management Journal, 6 (2), 23-33. https://doi.org/ 10.31357/hrmj.v6i2.3587.

Wickramasinghe, V. (2009). Predictors of job satisfaction among IT graduates in offshore outsourced IT firms. Personnel 
Review, 38 (4), 413-431. https://doi.org/10.1108/004834 80910956355 .

Wickramasinghe, V. (2010). Impact of time demands of work on job satisfaction and turnover intention. Strategic Outsourcing: An International Journal, 3 (3), 246-255. https://doi.org/10.1108/175382 91011093820.

Wijebandara, H. M., Malalage, G. S., \& Fernando, W. R. (2019). Factors affecting employee turnover intention among nonmanagerial employees in selected financial companies in Colombo district. Kelaniya Journal of Human Resource Management, 14 (1), 33-53. http://doi.org/10.4038/kjhrm.v $14 \mathrm{i} 1.65$.

Wimalasiri, H. S., \& Jayatilake, L. V. (2016). Factors affecting the employee turnover intention: Special reference to machine operators in apparel industry in Sri Lanka. 4th Students' International Conference on Business (SICB 2016) (p. 19). Colombo: Faculty of Commerce \& Management Studies, University of Kelaniya.

Yang, J., Huang, Y., \& Zhou, S. (2021). Emotional labor directed at leaders: the differential effects of surface and deep acting on LMX. The International Journal of Human Resource Management, 32 (9),
2070-2089. https://doi.org/10. 1080/09585192.2019.1579253.

Yorulmaz, M., \& Sevinc, F. (2021). Supervisor support and turnover intentions of yacht captains: the role of workfamily conflict and psychological resilience during the COVID-19 pandemic. International Journal of Contemporary Hospitality Management, 35(5), 15541570. https://doi.org/10.1108/ IJCHM-07-2020-0788.

Yusliza, M. Y., Faezah, J. N., Muhammad, J. S., \& Ramayah, T. (2021). Analysing the relationship between supportive work environment and employee retention. 11th Annual International Conference on Industrial Engineering and Operations Management (pp. 3088-3096). Singapore: IEOM Society International.

Yusliza, M. Y., Faezah, J. N., Noor, N. M., Ramayah, T., Tanveer, M. I., \& Fawehinmi, O. (2021). Effects of supportive work environment on employee retention: the mediating role of person-organisation fit. Industrial and Commercial Training, 201-216. https://doi.org/10.1108/ICT12-2019-0111.

Yusof, J., Ibrahim, F. A., Senin, M. S., Hassan, H. B., \& Nordin, M. N. (2021). Elements of work 
environment In the construct of special education teacher workload In Malaysia. Turkish Journal of Computer and Mathematics Education, 12 (11), 5284-5288. https://www. turcomat.org/index.php/turkbil mat/article/view/6750.

Zhang, Y. (2016). A review of employee turnover influence factor and countermeasure. Journal of Human Resource and Sustainability Studies, 4 (2),

85-91. https://doi.org/10.4236/jhrss.20 16.42010 .

Zhou, H., Long, L. R., \& Wang, Y. Q. (2009). What is the most important predictor of employees' turnover intention in Chinese call centre: job satisfaction, organisational commitment or career commitment? International Journal of Services Technology and Management, 12 (2), 129145. https://doi.org/10.1504/ IJSTM.2009.025231. 